\title{
The Rise of Container Tonnage and Port Developments in East Asia
}

\author{
Mariner Wang \\ Correspondence: Dr., Professor Mariner Wang, Graduate School of Management, Ritsumeikan Asia Pacific University, \\ Beppu, Japan
}

Received: August 6, 2015 Accepted: August 13, 2015 Online Published: August 27, 2015

doi:10.11114/bms.v1i2.1009

URL: http://dx.doi.org/10.11114/bms.v1i2.1009

\begin{abstract}
1990's saw the robust expansion of international trade in East Asia generating a remarkable record high and sustained economic growth unmatched by any other region in the world. In line with this, container tonnage in the region has been ever increased annually.

In light of this, the governments in the main ports of the region have plunged substantial investment in expanding and developing new container terminals to cope with the ever increased cargoes out/to the region. Though Lehman Shock in 2008 has given a huge impact on the container volumes in Asia, ports in the East Asia are seen to continue to handle the lion's share of global container business.

In 2013, the container throughput of East Asia accounted for 51.2 per cent out of that of the world, becoming the world container center.
\end{abstract}

Keywords: East Asia, Plaza Accord, Container throughput, Twenty Equivalent Unit (TEU), real GDP growth rate, load centre, port development

\section{Introduction}

After World War II, East Asia (Japan, China, the Asian NIEs, ASEAN 4) (Note 1) has enjoyed a remarkable record of high and sustained economic growth which grew faster than all other regions of the world (Note 2). East Asia's economic prosperity can be proven by its real GDP growth rate.

In the period between 2001-2014, the Asian NIEs (Hong Kong, Singapore, Taiwan, Korea), ASEAN 4 (Philippines, Malaysia, Thailand, Indonesia) and China have experienced average real GDP growth rate of 4.0, 4.5, 9.8 percent respectively compared to an average 0.85 percent in Japan, 1.8 percent in the U.S. and 3.8percent in the world (See Figure 1).

The contrast is even more pronounced when the growth of per capita income across developing regions is compared. The high economic growth in East Asia, particularly the Asian NIEs, which has been showing high real GDP growth rate in comparison with other regions or countries during the same period is, en facto, closely related to the booming international trade being conducted regionally and globally, imparting to East Asia an extraordinary dynamism which greatly changed the shipping environment in East Asia (Wang, 1997). 


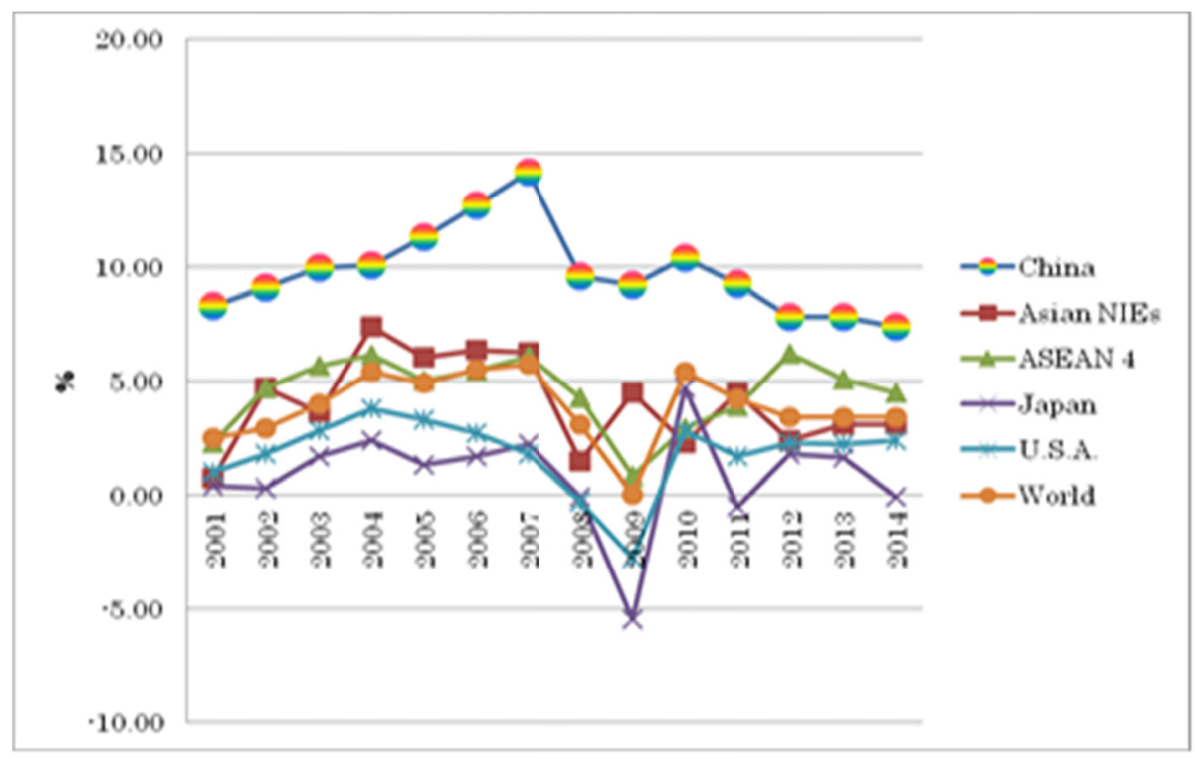

Figure 1. Real GDP Growth Rate of Asia, U.S. and World

Note: Real GDP growth rates are calculated by simple average.

Source: International Financial Statistics Yearbook, 2003- 2014, IMF, Trading Economics.

East Asia's economic prosperity can be dated back to the September 1985 "Plaza Accord" by the G5, namely, Group of 5 (The U.S., UK, Germany, France, Japan) intervening in the currency markets to drive the dollar drastically low against the Japanese yen, expediting the second wave of Japanese enterprises' overseas forays in Asia region. As a consequence, the international trade in East Asia has grown enormously, thereby generating a remarkable record of high and sustained economic growth unmatched by any other region in the world (Wang, 2003).

Triggered by this force, the volumes of shipping have risen steeply, generating a large concentration of container tonnage in East Asia. Taking year 2014 for instance, night main ports in East Asia are out of the world top 10 container ports. Of particular, in year 2001, Port Shanghai in China had surpassed port of Rotterdam joining port of Hong Kong, Singapore, Kaohsiung and Busan as the top five out of the world top 10 container ports (See Figure 2).

The drastic economic growth of East Asia was certainly not accomplished overnight. In the 1960's Japan became the focus of global attention as an emerging economic power catching up with the U.S. and Europe. The economic growth in Japan was soon followed by Asian NIEs (particularly, Taiwan and Korea), then ASEAN countries came to realize their vast potential for dynamic progress. Next, China started a giant stride. In other words, in East Asia, one country after another has played the role of a forerunner, pulling the rapid economic growth of the entire region (Wang 2003). This is the single most important factor behind the rapid upswing of East Asia on the global scene) (Note 3).

This paper falls into four main sections. The first discusses the surge of container transportation in East Asia. The second analyzes the weight of East Asia in global container tonnage. The third illustrates the expansion and development of container terminals in the main ports of East Asia, while the final section concludes by discussing the possible sustainability of container tonnage in East Asia toward the 21 st century. 


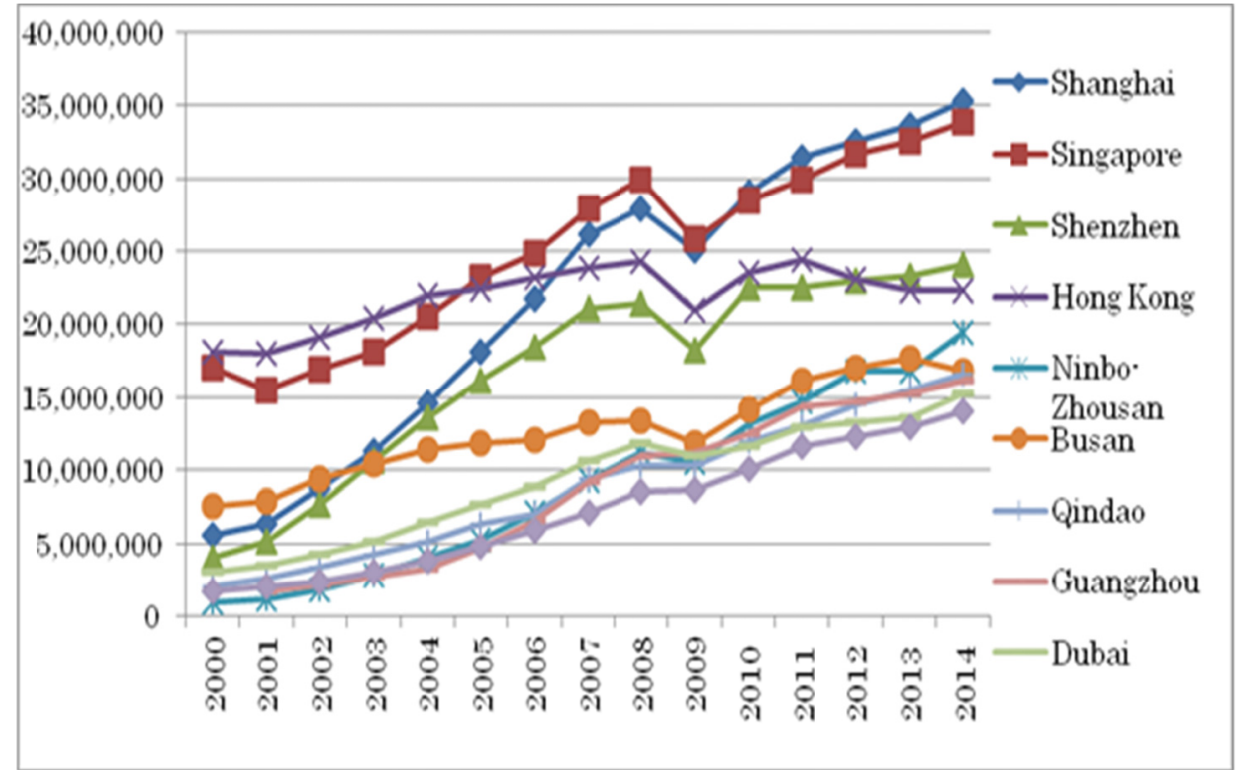

Figure 2. Annual throughput of World Top 10 Container Ports (2000-2014)

Source: Containerisation International Yearbooks, 2002-2014, Containerisation International,March, 2015

\section{The Surge of Container Transportation in East Asia}

Figure 3 illustrates the world's container traffic flow in 1990 and 2012. In 1990, the world's top trade line- the Trans-Pacific (Asia/North America) service handled 5.34 million TEUs, however, in 2012 the traffic volume reached to 21.92 million TEUs, an increase of 4.1 folds over 1990. On the other hand, during the same period the container volume handled in the Asia/Europe service, ranking second in terms of container tonnage, was 2.89 million TEU, however, in 2012 the traffic volumes reached to 19,61 million TEU, a 6 folds increase over 1990.

Shifting the focus onto the Intra-Asia trade (Japan, China, the Asian NIEs, ASEAN 4). In 1990, container traffic volume handled in the region was 3.5 million TEU. It is understandable that the scale could hardly compare with trans-Pacific and the intra-European (EU) service; however, it surpassed the traffic volume in the Asia/Europe service's 2.89 million TEU and the trans-Atlantic service's 3.05 million TEU.

In comparison, in 2012, the container traffic volumes in the intra-Asian service reached to 56.1 million TEU. The figure could hardly rival the scale of the trans-Pacific service's 21.92 million TEU, however, it paralleled Asia/Europe service's 19.61 million TEU and outpaced the trans-Atlantic service's 6.3 million TEU (Wang, 2014a). Clearly, the intra-Asian service, with its buoyant economic growth, has become the newly emerging force of the world container traffic services (Note 4).
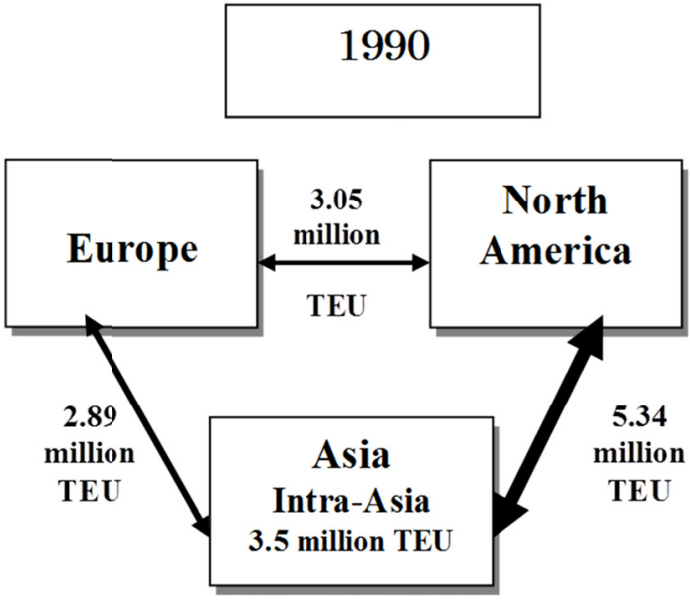

Figure 3. Weight of Intra-Asian Service in the World Container Traffic

\section{2}

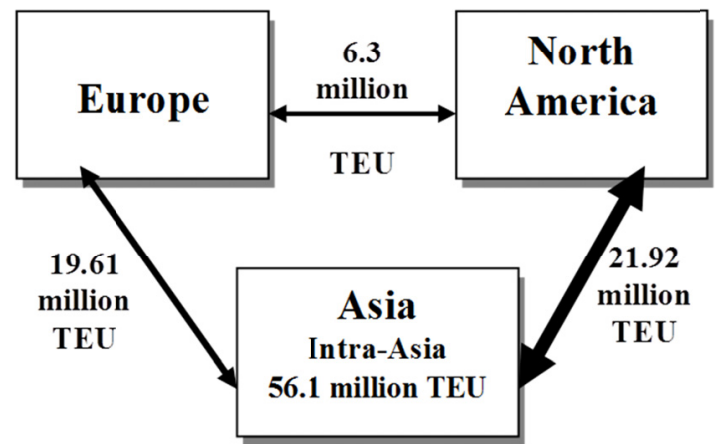


Source: Maritime Report 2005, 2014, Ministry of Land, Infrastructure, Transport and Tourism.

\section{The Weight of East Asia in Global Container Tonnage}

As has been already mentioned, the container traffic tonnage in intra-Asian service, particularly in the Asian NIEs has been increasing substantially during the last decade. In this section, the status of East Asia as well as the Asian NIEs in the world from the viewpoint of container tonnage will be discussed.

Table 1 demonstrates the container throughput by region and country as well as their weight in comparison to the world's total container traffic spanning from 1985 to 2013. It is evident from the table that during the period the container throughput in East Asia rose from 15.9 million TEU to 333.5 million TEU accounting for from 28.5 per cent to 51.2 per cent out of the world's total container tonnages respectively (Wang, 2014a).

It also can be realized that during the same period, the weight in ASEAN 4 rose from 3.0 per cent to 7.0 per cent, while China rose from 0.8 per cent to 20.1 per cent. In comparison, the container cargo throughput in the U.S. declined from 20.6 percent to 6.8 per cent. Overall, it is apparent that main ports in Asian NIEs, ASEAN4 as well as China have contributed largely to the substantial growth of container traffic tonnages in East Asia as a whole (Note 5).

\section{Port Developments in East Asia}

For the last past two decades, ports development has become a trend in East Asian region. The back ground behind the ports development is seen as follows.

1. To provide more space for handling the yearly ever increased containerized cargoes.

2. To provide deep sea port for accommodating super large container vessels.

In this section, the large scale ports developments in East Asia are introduced.

\subsection{Port of Singapore}

The port of Singapore is the load centre of container ports in Southeast Asia. PSA International, a wholly-owned affiliated company of state-operated Temasek Holdings Pte. Ltd (Note 6), with an aim to developing 23 container berths and three car berths for Phase 1 and 2 at Pasir Panjang Terminal (PPT) 1-3, has invested some S\$5 billion (US\$3.5 billion). To date, 23 berths at PPT 1, 2, 3 and 5 berths at PPT 5, in total 28 berths are in operation (Wang, 2014a).

As of July 31, 2015, PSA International operates total of 57 container berths with a total capacity of over 35 million TEU. To meet the needs of shipping lines in the future, PPT Phase 3 and 4, comprising some 16 berths have already been planned. When completed, they will provide an additional 14 million TEU capacity, lifting the Port of Singapore's total capacity to over 50 million TEU (49 million TEU from PSA Singapore Terminals and 1.8 million TEU from Jurong Port). The Maritime and Port Authority of Singapore (MPA) has begun land reclamation for Phase 3 and 4 and work is under proceeding.

Table 1. Status of East Asia in World Container Throughput (Unit: 1,000 TEU)

\begin{tabular}{lllllllll}
\hline $\begin{array}{l}\text { Country/ } \\
\text { Region }\end{array}$ & 1985 & 1990 & 1995 & 2000 & 2005 & 2010 & 2013 & $2013 / 1985$ \\
\hline Japan & 5,517 & 7,956 & 10,604 & 13,129 & 17,055 & 17,727 & 19,688 & 3.6 \\
(\%) & $9.9 \%$ & $9.3 \%$ & $7.7 \%$ & $5.7 \%$ & $2.3 \%$ & $3.5 \%$ & $3.5 \%$ & \\
Asian NIES & 8,309 & 18,124 & 36,748 & 54,736 & 73,698 & 84,326 & 93,983 & 11.3 \\
$(\%)$ & $14.9 \%$ & $21.2 \%$ & $26.8 \%$ & $23.6 \%$ & $18.8 \%$ & $16.7 \%$ & $14.4 \%$ & \\
ASEAN 4 & 1,657 & 4,298 & 7,977 & 15,348 & 26,279 & 34,741 & 45,778 & 27.6 \\
(\%) & $3.0 \%$ & $5.0 \%$ & $5.8 \%$ & $6.6 \%$ & $6.7 \%$ & $6.9 \%$ & $7.0 \%$ & 390.3 \\
China & 446 & 1,204 & 4,682 & 22,884 & 67,245 & 125,103 & 174,080 & 390.3 \\
(\%) & $0.8 \%$ & $1.4 \%$ & $3.4 \%$ & $9.8 \%$ & $17.2 \%$ & 24.8 & $20.1 \%$ & 20.9 \\
East Asia & 15,928 & 31,582 & 60,011 & 106,097 & 184,277 & 261,897 & 333,529 & \\
(\%) & $28.5 \%$ & $36.9 \%$ & $43.7 \%$ & $45.8 \%$ & $47.0 \%$ & $52.0 \%$ & $51,2 \%$ & 3.8 \\
U.S.A. & 11,533 & 15,245 & 19,104 & 27,315 & 38,498 & 35,601 & 44,255 & \\
(\%) & $20.6 \%$ & $17.8 \%$ & $13.9 \%$ & $11.8 \%$ & $9.8 \%$ & $7.1 \%$ & $6.8 \%$ & \\
World & 55,903 & 85,597 & 137,239 & 231,689 & 391,883 & 503,512 & 651,099 & 11.6 \\
\hline
\end{tabular}

Source: Based on the data from Containerisation International Yearbook, 1987-2013.

On the other hand, PSA International's globalization efforts have now become a significant part of the group's business. Since embarking on its first project in port of Dalian, China in 1996, PSA International's global business has achieved tremendous growth. Up to July 2015, PSA International has been involved in developing, managing and operating thirteen overseas ports in 15 countries (Singapore, Thailand, Vietnam, Indonesia, China, South Korea, Japan, India, Saudi Arabia, Belgium, Italy, Portugal, Portugal, Argentina, Panama and Columbia) around the globe.

PSA International, with an aim to providing dedicated berths for shipping lines, has signed joint venture contracts with 
COSCO (China), MSC (Swiss), PIL (Singapore) for COSCO-PSA Terminal (CPT), MSC-PSA Asia Terminal (MPAT), and PIL-PSA Singapore Terminal (PPST) which began operation from year 2003, 2006 and 2008 respectively.

PSA International's global network strategies widened significantly when Belgian terminal operator Hesse Noord Natie was brought into the fold in March 2002. The acquisition of 80 percent of Hesse Noord Natie (HNN), is PSA International's largest single foreign investment to date and give it a strong foothold in the North European market. In addition, in 2001, PSA International also began on the Greenfield port developments in Port of Incheon, South Korea and Sines container terminal (hereinafter referred as CT) in Portugal (Note 7). These projects are expected to contribute significantly to PSA International's growth and have attracted international attention to the group.

Moving ahead, PSA International has been vigorously pursuing overseas expansion and the development of its IT (Information Technology) services. In 1999, PSA Corporation and Hong Kong's China Merchants Holdings (CMH) Group have formed a new logistics company in China named the China Merchants-PSA Logistics Network Co. Ltd. Aiming to be a full-fledged logistics providers, the company has since secured a number of logistics contracts in major cities including Shanghai, Guangzhou, Tianjin with multi-national companies and their representatives, such as Philips Lighting and Tiat Trading, the distributor for Heineken Beer and Evian Natural Spring Water.

PSA International also has been quite aggressive in the introduction of port IT. For example, Pornet.Com is aiming to introduce PORTNET (Note 8) -the world's first and only truly nation-wide and industry-wide e-business network that has the participation of the entire shipping and port community operating through Singapore - to ports and around the world. It has successfully implemented customized versions of PORTNET overseas, such as Port of Dalian in China, Voltri Terminal in Italy .

PSA International has also teamed up with British P\&O Ports to acquire a stake in P-Serve Technologies (PST), a provider of internet-based track and trace solutions. Under an agreement signed by the three parties, PST will provide the infrastructure and project management while PSA International and $\mathrm{P} \& \mathrm{O}$ will market the solution, eLogicity, to their customers through their respective ports and logistics business.

As a maritime hub encompassing the whole range of services, PSA Singapore Terminals, with on-going liberalization of financial and telecommunication services, will be an even bigger attraction to more carriers to call (Note 9).

\subsection{Port of Shanghai}

In recent year, the exports of China have moved into high gear to supply the needs of expanding world trade, and the port of Shanghai has become the big beneficiary from ever increasing trading to Asia, Europe and North America. It has been retaining its status as the leading container port in China.

Container throughput at port of Shanghai was surprisingly resilient in 1998, it handled 3.05 million TEU, up 21 percent on the previous year's 2.53 million TEU, placing Shanghai tenth in the world ranking (See Figure 2). In 2001, it demonstrated an 11 percent increase in container throughput over year 2000 to 6.33 million TEU, placing itself as the fifth in the world rankings. The remarkable achievement was due to the operation of the new five terminals in Pudong area and the introduction of world-class port management expertise in Hutchison Port Holdings to manage Shanghai Container Terminals (SCT). These factors have driven the rapid ascent of Shanghai port through the world rankings.

Port of Shanghai has been tipped to attain pivotal position in the global container ports league in 2009, failed to overtake Singapore. It suffered the ignominy of seeing its growth rate coming in at a slightly slower pace than that of its Asian rival. Port of Shanghai, located at the center of east coasted of China, has a number of original container terminal owned and operated by Shanghai Container Terminal Ltd. (SCT) in the Wusong Port Area. They are Zhanghuabang, CT, Jungonglu CT and Baoshan CT. SCT comprises 10 berths located on the bank of the Huangpu River, with a combined annual capacity of 4 million TEU (Wang, 2014a).

Another major facility is the Waigaoqiao CT ideally located in China's largest multi-purpose Foreign Trade Zone (FTZ), the Waigaoqiao FTZ. All five CT in Waigaoqiao, comprising 16 berths, have been in operation, with a combined capacity of 15 million TEU (Twenty Equivalent Unit). Since the operation of the newly developed deepwater Yang Shan CT (Wang, 2012), located at offshore to the east of Shanghai, a large portion of transhipment cargo arriving at Shanghai Port have been discharged at Waigaoqiao CT and then transferred to Yangshan CT by shuttle barge with the loading capacity of $350 \mathrm{TEU}$ operating on a scheduled basis. It takes eight hours to transport containers between Waigaoqiao CT and Yangshan CT (Note 10).

Yangshan CT, operated by the Shanghai International Port Group (SIPG), is located on two large islands known as Little Yangshan Island and Big Yangshan Island, which are connected to the mainland by the six-lane, $32.7 \mathrm{~km}$ Donghai Bridge, believed to be the longest bridge in the world. Yangshan Port is the biggest port in China, involving a total planned investment of some RMB 100 billion (US\$14.4 billion). Development (phase 1-phase 4) will continue until 2020, when completed, the facility will be equipped to have an annual capacity of more than 20 million TEU Wang, 
2012).

Phase 1 comprises five berths with a capacity of 4 million TEU, while phase 2 consists of four berths with a capacity of four berths with a capacity of 3.2 million TEU. Phase 3A/3B comprise 7 berths with a length of 2,600 m and an alongside water depth of 17.5 million, the deepest berths in Shanghai.

Being appointed by Shanghai Tongsheng Investment Group, the developer of Yangshan CT, SIPG operates three of the phase 3B berths capable of handling 2.4 million TEU annually starting operation in 2009. When phase 3B is fully completed, phase 3, as a whole, will have seven berths with a total capacity of 5.6 million. As of July 2015, port Shanghai has 46 container berths with a total capacity of over 35 million TEU. It serves 45 international shipping lines, which link it to more than 300 ports worldwide.

\subsection{Port of Hong Kong}

Port of Hong Kong is the hub port serving the South-East and East Asia region, and is an important economic gateway to southern mainland China. Hong Kong set a record in its container throughput in 2007 by handling 23.9 million TEUs, attaining its status as the largest container port in the world. Port of Hong Kong dominates the central cluster, and its continuing high growth reflects the rapid economic development in the region. In 2014, it handled 22.3 million TEUs ranking the $4^{\text {th }}$ in the world next to port of Shanghai, Singapore and Shenzhen (Southern China).

Given its business friendly environment and world class infrastructure, Port of Hong Kong is not only blessed with its unique geographical advantage bearing mainland China as the hinterland, but also plays the vital role as the entrepôt for container transhipment for both Asia/North America and Asia /Europe traffic lines.

Additionally, it provides the feeder services for the export and import cargoes between inland of China and the adjacent Pearl River Delta (Wang, 2014). For those reasons, port of Hong Kong has been the leading container port in the world.

Growth at the port is boosted by the development of the $\$ 2$ billion invested container terminal 9 operated by HIT (Hong Kong International Terminals) and MTL (Modern Terminals Ltd.). The terminal is located in Tsing Yi areas just opposite side of the Kwai Chung container terminal. The new facility occupies an area of 70 hectares of reclaimed land consisting of four deep-sea berths and two feeder berths.

\subsection{Port of Pusan}

Port of Pusan, lying on the southeast coast of Korean peninsula facing the Korea Strait, plays a pivotal role as the transhipment hub in northeast Asia. The 2000 increase of 17.1\% in containers handled in South Korea jumped by its highest margin since the 1995 Kobe earthquake when port of Pusan won a big piece of Japan's transhipment cargo. In 2014, it handled 16.8 million TEUs ranking $6^{\text {th }}$ in the world next to Ningbo-Zhoushan located at the eastern coast of China. Container throughput is expected to increase annually because port of Pusan's role as a container hub for north Asia has become more and more realistic.

Additionally, the Korean government, with an aim to attaining balanced national land development and to smoothly cope with the drastic increase of container volume resulting from brisk Korean economic growth, in 1994 consigned Korea Container Terminal Authority (KCTA) to launched an intensive short, middle and long term port development projects.

Those projects incorporated into the middle term projects include port development and expansion projects in Gamman port known as Busan port phase 4 development (1991-1997); Pusan New Port Container Terminal (PNCT, 2001-2007) and Kwangyang CT (phase1:1987-1997, phase 2:1996-2004, phase 3-1, 3-2:1999-2011) (Wang, 2012) ; South port of port of Inchoen (2001-2003).

PNC is part of a new port development that will be fully completed by 2015. It will comprise 25 new container berths, with possibilities for future expansion. The new port will be able to handle future-generation vessels of 12,000 TEU and will increase Pusan's overall handling capacity by more than 15 million TEUs.

Costing US\$7.2 billion from the private sector, PNC is the first port development project in South Korea to be funded by private capital including DP World, Samsung Group, Hanjin shipping and Hyundai Merchant Marine . It will be a nine-berth facility, with the six berths of phase 1 stretching along 2,000 meters of quay line, an initial depth alongside of 16 meters and a capacity of 3.6 million TEUs. The final three berths of phase 1-2, stretching along 1,200 meters with an initial depth alongside of 17 meters and a fully automated yard operation system, were completed in May 2009, boosting the complex's annual capacity to 5.5 million.

PNCT finalized a contract with world renowned shipping company-MSC in April 2009 and in May, MSC began moving its vessels to PNC, which will contribute to an annual volume increase of about 600,000 TEUs. In addition, French based CMA CGM brought three services to PNCT on May 16, 2009. On May 20, 2009, Hanjin Shipping's Pusan New Port phase 2-1 terminal, operated by Hanjin New Port Company, was officially opened. The terminal has 
three berth with a depth of 18 meters, capable of accommodating three 12,000 TEUs super container vessels simultaneously (Note 11). The terminal has also introduced the world's first automated horizontal yard crane system.

In June 2009, Busan Port Authority (BPA) announced an international bid to buy the operational rights for the three berths of PNCT's phase 1-1, which has been operating far below the maximum capacity since its opening in 2006. On the other hand, CMA CGM acquired a 12\% stake in PNCT, with a concession to operate phase2-3 of Busan New Port for a period of 29 years-CMA CGM's initial port investment in South Korea. The new terminal began operation in late 2012 and operated in partnership with Macquarie, Bouygues, Hyundai Development, KMTC, Busan Port Authority and local operators KUKJE and KCTC.

\subsection{Port of Gwangyang}

Port of Gwangyang is on the south-central coast of South Korea. The port is about 125 kilometers west-southwest of port of Pusan. The port lies on a naturally protected deep-water harbor, and its channels allow vessels up to 300 thousand tons to arrive and depart at any time. The harbor's 16 meter depth allows to accommodate 8th generation container vessels and operate throughout the year (Wang, 2012).

In 1998, phase 1 of the CT began operation then followed by phase 2-1, phase 2-2 and phase 3-1 opened in 2002, 2004, 2007 respectively. As of July 2015, the container terminal operates 18 berths and plans further development.

Port of Gwangyang boasts state-of-the-art logistics services, including a $100 \%$ on-dock system and ample equipment to handle container mega-carriers with fast loading/unloading rates. The advanced IT backing terminal operations and automated gate services make operations efficient and affordable.

Yeosu Gwangyang Port Authority is committed to expanding port of Gwangyang facilities until 2020, adding annual handling capacity of more than 12.4 million TEUs to make the port of Gwangyang an international container hub for Northeast Asia. port of Gwangyang completed a distripark container terminal of some 190 hectares in 2008 and expanded the facility to 390 hectares in 2011.

The period of development of Gwangyang Port Container Terminals (GPCT) spans from 1987 through 2020. phases 1, 2, and 3-1 are already completed. phase 3-2 completed in 2011 provides an additional 1260 meters of quays. These expansions will add handling capacity of 1.37 million TEUs per year.

A joint logistics center built behind GPCT transforms port of Gwangyang into a high value-added center based on an effective business model which covers the full range of logistics functions including storage, assembly, processing, and distribution. The Joint Logistics Center was completed in 2007 containing total floor space of 33.2 thousand square meters. GPCT is continuing its aim of becoming a global logistics hub through its Distripark (3.88 million square meters), an enormous project comprising the Eastern and Western Distripark complexes. Designated as a FTZ, the Distripark is being developed in phases on reclaimed land behind the container terminals.

As South Korea adds container capacity, this will fuel the preference for shipping lines to use port of Gwangyang as a hub to avoid expensive Japanese port charges and also access the increasingly attractive mainland China market. Additionally, the restoration of rail links between North and South Korea triggered by the Seoul-Pyongyang rapprochement in 2000 will be an opportunity for both South and North to make another great leap forward (Note 12).

When the talk between South and North Korea goes smoothly, GPCT will be linked by rail between South and North Korea to the Trans-Siberian Railway and the Trans-China Railway. Coupled with the above mentioned port development plans will strengthen the Korean Peninsula's claim to be a major hub of northeast Asia (Wang, 2014b).

\subsection{Port of Kaohsiung}

Port of Kaohsiung, with its geographical advantage located along the southwestern coast of Taiwan on the key trade lanes running through the Taiwan Strait, is the largest international seaport in Taiwan handling $73 \%$ of its container throughput. The port is ideally located as the transhipment hub for the export cargoes between the west coast of North America to Southeast Asia.

Furthermore, owing to the opening of direct sailing between port of Kaohsiung and port of Xiamen and Fuzhou (Fujian Province) in China in 1997, it provides port of Kaohsiung with more room for securing the transhipment cargoes from North America and China.

The historic agreement signed in November 2008 permitting completely direct cargo transport between Taiwan and mainland China saw the trade route re-open in December 2008, after an interruption of nearly 60 years. This means that freight (cargoes) can be shipped directly across the Taiwan Strait from 63 Chinese ports, without having to make a detour via the port of Ishigaki (Okinawa island, Japan). This saves between 16 and 27 hours of shipping time for Taiwanese vessels, as well as around $15-30 \%$ on cost. 
As a driving force, port of Kaohsiung expects cargo flows to increase significantly. In order to add capacity to cope with these potential increased volumes, port of Kaohsiung is constructing a sixth container terminal with four berths, 17 meters depth alongside and a capacity of 2.8 million TEU, on a 50 year operation concession (on BOT basis). Named the Kaohsiung International Container Terminal (KICT) (Wang, 2014a), it is operated by Kao Ming Container Terminal Corporation (KMCT), a wholly-owned subsidiary Taiwan's national sipping line-Yang Ming (Note 13).

KMCT has agreed a US\$500 million loan to finance the project and the first two berths, capable of accommodating 10,000 TEU super-size container vessels commencing operation in 2011, with the remaining two began operation in 2013 (Note 14). KMCT is a semi-automated terminal and its four berths are equipped with 12 quay cranes and sets of automated tail-mounted gantry cranes (ARMGs) (Note 15).

\section{Conclusion}

The concentration of container tonnage in East Asia and the intensity of operations are significant not only in regional but also in international terms. Nor is it the simple magnitude involved that make regional concentration significant.

It is also the way in which the ports in East Asia are linked together into global and regional shipping networks. The shipping lines' hub and spoke strategy by deploying large container vessels and feeder services focuses on large flows of containers and shipping capacity on to a small number of extremely efficient ports; this, combined with the further distribution capacity of these ports, gives East Asia particular significance at both global and a regional scale.

Thought a worldwide downturn in demand triggered by Lehman Shock in September 2008 saw outbound volumes plummeted by some 20 percent in the last half of 2009, the world market was on the rebound from early 2010 following months in the doldrums, the majority of China ports showed an increase in general cargo volumes in international trade in 2009 compared with that in 2008. Despite the recession-hit world economy, the top 10 container ports in China registered growth (See Figure 4).

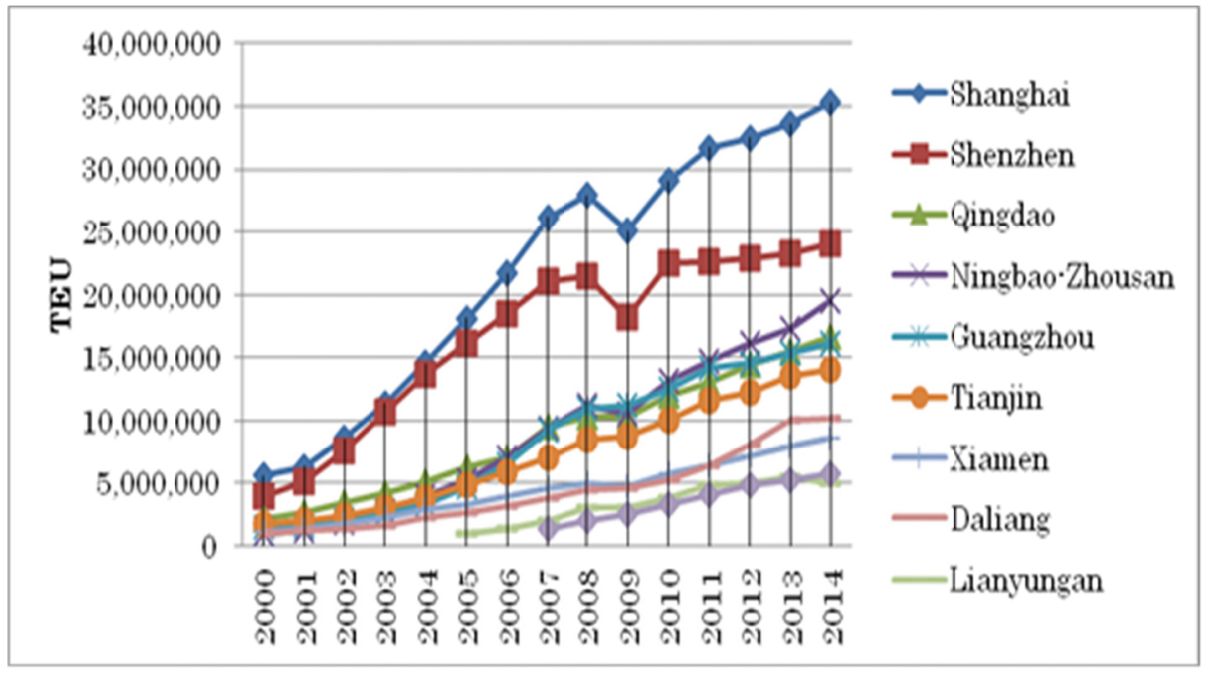

Figure 4. Container throughput at the Major Chinese Ports (2000-2014)

\section{Source: statistics data of Ministry of Transportation, China.}

The economic crisis-induced stagnant growth has come to an end. The Asian region has generally turned the corner and is now heading towards economic recovery though the growth is set to slow. World economic growth and world trade are forecasted to improve further in 2000, with estimates for world trade growth at 7.1 percent against 4.5 percent in 1999. Given that a sustained economic cyclical upswing is now underway, the robust performance can be attributed to the acceleration of Asian economic recovery plus an upturn in transpacific shipments in the second half of 1999.

Asia has greatly enhanced its status as a container-owing region, accounting a third of all TEU in 2009, compared with $15 \%$ back in 1978. This resulted in an ownership of TEU for the entire Asian region and represented a 30-fold plus increase on the 294,000 TEU reported 30 years earlier. Back then, half the entire Asian total was controlled by Japanese firms with the only other significant holding to be founded Hong Kong and Taiwan.

Not surprisingly, more ocean carriers have reported significantly reduced profits in 2008 and 2009 compared with 2007. The East Asia region still offers the global container industry some of the best growth and investment prospects.

According to the analytic report from Containeirsation International Market Analysis 'The World Container Census 2001', global container output, after remaining largely static for several years, increased by 25 percent in 2000 to a new 
record high of more than 1.85 million TEUs. The rise in container production was firmly underpinned by improved global trade growth during 2000 and a record delivery of over 600,000 TEUs of additional vessel slots in the same year. Additionally, the world fleet of containers will grow by 40 percent over the next three years, to reach 20.9 million TEUs by 2005 , representing a year-on-year growth of 8.5 percent.

As has already shown on table 1, the share of East Asia in the world container market has risen to 51.2 percent in 2013--equal to a massive 333 million TEUs, making it undoubtedly the world center of liner shipping operations. In that decade, the main countries in the region, particularly the China will make a further big leap in container throughput performance.

\section{References}

Efforts to increase use of Port Klang. (1998). New Straits Times. Kuala Lumpur, Malaysia: the New Straits Times Press (M) Bhd.

Korea Free Economic Zone http://www.fez.go.kr/jp/gwangyang-bay-fez-overview.jsp

Malaysia vs. Singapore: A new spin in the anti-complacency drive. (1997, January 17), Asiaweek. Hong Kong:Time Inc.

Mariner Department of Hong Kong http://www.mardep.gov.hk/en/home.html

Port of Kaohsiung, Taiwan International Ports Corporation, Ltd. http://kh.twport.com.tw/en/

PSA https://www.singaporepsa.com/

PSA https://www.globalpsa.com/

Shanghai International Port (Group) Co. Ltd. http://www.portshanghai.com.cn/en/

Wang, M. (1997). The Rise of International Trade and Global Logistics in East Asia: The Case Study Emphasizing Asian NIEs. Study of Shipping Economy (pp. 117-135), Japan Society of Shipping Economics.

Wang, M. (2003). The Status of East Asian Hub Ports in Global Logistics. Ports and Harbors. Tokyo, Japan: Ports \& Harbors International Association.

Wang, M. (2012). The Knowledge of Global Logistics in East Asia (2nd ed.). Beppu, Japan: TENDODO BOOKS.

Wang, M. (2014 a). The Global Logistics System in East Asia(2nd ed.). Beppu, Japan: TENDODO BOOKS.

Wang, M. (2014 b). Global Logistics and Shipping Alliance. Beppu, Japan: TENDODO BOOKS.

World Top Container Port. (2014). Container Management. Surrey, U.K.: Marshall House.

Yeosu Gwangyang Port Authority http://www.ygpa.or.kr/jp/yeosu_gwangyang/yeosu_port/general_status/

\section{Notes}

Note 1: The Association of Southeast Asian Nations, or ASEAN, was established on 8 August 1967 in Bangkok, Thailand, with the signing of the ASEAN Declaration (Bangkok Declaration) by the Founding Fathers of ASEAN, namely Indonesia, Malaysia, Philippines, Singapore and Thailand. Brunei Darussalam then joined on 8 January 1984, Viet Nam on 28 July 1995, Lao PDR and Myanmar on 23 July 1997, and Cambodia on 30 April 1999, making up what is today the ten Member States of ASEAN.

Note 2: Major elements which contributed to the phenomenal economic development of East Asia:1) In most countries of East Asia there is a strong national aspiration toward development which is shared not only by the government but also by the vast majority of the people. 2) In the process of realization of the national aspiration, public and private business sector successfully maintained an efficiently cooperative division of labour and established an export-oriented industrial structure. With few exceptions, East Asian governments demonstrated enlightened leadership with a right set of policy objectives. And at the same time, there was market-oriented private sector dynamism with abundant innovative entrepreneurship. Furthermore, both public and private sectors did not confront each other rather, they supported each other. 3) Most East Asian countries enjoyed a high savings ratio, which enabled vigorous accumulation of domestic capital. Additionally, labour ethics in general were sound, which generated high productivity. 4) East Asia 
could enjoy favourable external support. In the first place, the U.S. provided a vast open market for the East Asian exports. It was also the U.S. which guaranteed the security of the region. Japan also played a crucial role in stimulating East Asian economic development by supplying capital, technology and managerial know-how since the 1980's.

Note 3: Mariner Wang (2012). The Knowledge of Global Logistics in East Asia (2nd ed.). Beppu, Japan: TENDODO BOOKs.

Note 4: Wang, M. (1997). The Rise of International Trade and Global Logistics in East Asia: The Case Study Emphasizing Asian NIEs. Study of Shipping Economy (pp. 117-135), Japan Society of Shipping Economics.

Note 5: Wang, M. (2014 a). The Global Logistics System in East Asia(2nd ed.). Beppu, Japan: TENDODO BOOKS.

Note 6: It is an investment company owned by the Government of Singapore. Incorporated in 1974, Temasek owns and manages a net portfolio of S\$266 billion (US\$177 billion; as of 31 March 2014), mainly in Singapore and Asia. It is an active shareholder and investor, and its portfolio covers a broad spectrum of sectors including financial services, telecommunications, media, technology, transportation, industries, life sciences, consumer, real estate, as well as energy and resources. Temasek has a multinational team of over 490 people, in 11 offices globally including London and New York. See https://en.wikipedia.org/wiki/Temasek_Holdings for more details.

Note 7: See The PSA Corporation Annual Report 2001, pp.42-43 for more details.

Note 8: PORTNET is PSA's unique user-friendly Internet system, it provides end-to-end e-commerce from the point of booking to the point of billing for shipping lines, shipping agencies, freight forwarders and shippers/consignees. Functions include track and track of cargo, submission of electronic bay plans, management of berthing schedules, submission of billing. It was developed in 1984 and was officially launched in 1989. With PORTNET, virtually every aspect of shipping can be managed online. In June 1999, it was also moved to the internet global platform.

Note 9: Singapore's successful formula in constantly upgrading port facilities was being adopted by its neighbors. Singapore now is facing competition from Malaysia, with its new container ports, airport, highways, railway, and multimedia corridor. However, the Transport Ministry of Malaysia is going to introduce legislation compelling local exporters to use Port Klang. The policy is to increase the RM200 Causeway levy on Malaysian lorries leaving the country. The levy for lorries leaving via the Causeway might be increased by 100 percent to RM400 or more. The proposed law may not require local exporters to immediately use Port Klang for 100 per cent of their cargo, but compel them to reduce the amount dispatched via Singapore within a time frame. Currently, 40 percent of an estimated 3 million TEUs of local cargo were being exports via Singapore. Of this volume, 45 percent originated from the Klang Valley. For more details, see "Efforts to increase use of Port Klang", New Straits Times, July 17, 1998, 8 and "Malaysia vs. Singapore: A new spin in the anti-complacency drive", Asiaweek, January 17, 1997, 20.

Note 10: Phase 2 and 4 at Waigaoqiao have been designated to handle transhipment cargoes. In January 2009, it was reported that construction of Waigaoqiao PhaseVI had begun, with completion scheduled for the end of 2010. PhaseVI will comprise three container berths with 2.1 million TEU capacity. SIPG is the main investor, with a US\$711 million contribution. Yangshan's deepwater facilities are more easily accessible than those at Waigaoqiao, which are subject to tidal limitations, and the deeper water and greater convenience of Yangshan have been seen increasing numbers of customers shift their services there from Waigaoqiao.

Note 11: Refer to "World Top Container Port" Container Management, 2009 for more details.

Note 12: The $318 \mathrm{~km}$ rail line from the South's capital of Seoul to the North's Sinuiju city bordering China, will lay the groundwork for an international railway. Not only will inter-Korea business generate more container throughput, but shippers in Japan and Korea will also get a faster, cheaper route to Europe initially via Pusan or Kwangyang port then via the Trans-Siberian Railway.

Note 13: Terminal six is scheduled to have an annualized throughput capacity of 2.8 million TEU with phase 1 of the development becoming operational in 2012. All four of the $350 \mathrm{~m}$ berths, with a depth alongside of $17.5 \mathrm{~m}$, should be in service by 2014. The new terminal will be capable of handling 10,000 TEU-sized super-sized container vessels.

Note 14: Currently COSCO, the national shipping in China, is said to be interested in obtaining a $20 \%$ stake in KICT.

Note 15: Total Soft Bank Ltd. (TSB) of South Korea will supply it with the latest versions of its CATOS and auto mated terminal solutions, its first installation of these in Taiwan.

\section{(cc) EY}

This work is licensed under a Creative Commons Attribution 3.0 License. 